\title{
PERSEPSI PEMILIH DISABILITAS TERHADAP PEMILU SERENTAK TAHUN 2019
}

\section{St. Syamsuri. R, Gustiana A. Kambo, Muhamad Rasman}

Universitas Hasanuddin Sulawesi Selatan, Indonesia

Universitas Hasanuddin Sulawesi Selatan, Indonesia

Universitas Halu Oleo Kendari Sulawesi Tenggara, Indonesia

Email: syamsurititi@gmail.com, gustianakambo@yahoo.com, mhrasman@gmail.com

\begin{tabular}{l}
\hline INFO ARTIKEL \\
\hline Diterima \\
25 Agustus 2021 \\
Direvisi \\
05 September 2021 \\
Disetujui \\
15 September 2021 \\
\hline
\end{tabular}

Kata Kunci: hak politik; pemilih disabilitas; perspektif

\section{ABSTRAK}

Undang-Undang Nomor 7 Tahun 2017 Pasal 5 tentang Pemilihan Umum dengan lebih spesifik mengutarakan kesempatan yang sama kepada penyandang disabilitas untuk terlibat dan aktif dalam politik yang merupakan hak azasinya sebagai warga Negara. Namun pada pelaksanaannya masih banyak terdapat kendala yang menghambat baik faktor eksternal maupun faktor internal dari penyandang disabilitas itu sendiri. Pada penelitian ini penulis ingin mendeskripsikan masalah internal dan eksternal tersebut dengan pendekatan kualitatif untuk mengetahui hal-hal yang mempengaruhi perspektif penyandang disabilitas dalam penggunaan hak politiknya khususnya pada pelaksanaan pemilu serentak tahun 2019 yang secara historis merupakan pemilu yang paling kompleks sepanjang pelaksanaan pemilihan umum secara langsung. Penelitian ini membahas tentang pemilih disabilitas pada pemilu serentak 2019 yang bertujuan untuk menggambarkan dan menganalisis pendekatan psikologi politik penyandang disabilitas dalam penerapan hak pilihnya. Metode penelitian yang digunakan adalah penelitiaan deskriptif kualititatif dengan metode wawancara, studi kepustakaan, dan pemberitaan media massa. Temuan dari penelitian ini menunjukkan beberapa masalah yang menjadi isu bagi pemilih disabilitas yang berakibat pada pentingnya sebuah perbaikan pelayanan dalam pemilu khususnya bagi pemilih disabilitas.

\section{ABSTRACT}

Law Number 7 of 2017 Article 5 concerning General Elections more specifically expresses equal opportunities for persons with disabilities to be involved and active in politics which is their human right as citizens. However, in its implementation there are still many obstacles both from external and internal factors that obstruct persons with disabilities. In this research, the writer wanted to describe these internal and external

$\begin{array}{ll}\text { How to cite: } & \text { St. Syamsuri. R, Kambo, G. A., \& Rasman, M., (2021) Persepsi Pemilih Disabilitas terhadap Pemilu } \\ & \text { Serentak Tahun 2019. Jurnal Syntax Admiration 2(9). https://doi.org/10.46799/jsa.v2i9.312 } \\ \text { E-ISSN: } & 2722-5356 \\ \text { Published by: } & \text { Ridwan Institute }\end{array}$


factorswith a qualitative approach. This aims to find factors that affect the perspective of persons with disabilities in the use of their political rights, especially in the implementation of the 2019 simultaneous elections, which historically were the most complex elections throughout the direct general election. This research discussed about voters with disabilities in the 2019 simultaneous elections aiming to describe and analyze the political psychology approach of persons with disabilities in the enforcementof their right to vote. The research method used was descriptive qualitative research with interviews, literature studies, and mass media reporting. The findings of this Keywords: political research indicated several problems that becameissues for right; voter with voters with disabilities which resulted in the importance of disability; improving services in elections, especially for voters with perspective disabilities.

\section{Pendahuluan}

Sejatinya satu suara dalam pemilihan umum apabila diabaikan dengan sengaja adalah merupakan pelanggaran yang dapat berujung pidana dimana satu suara tersebut dapat menjadi penentu untuk memenangkan perwakilan rakyat yang akan duduk dikursi eksekutif maupun legislatif. Sedemikian pentingnya hak politik tersebut sehingga ranah perundang-undangan mencoba mengakomodir dengan berbagai peraturan kepemiluan demi memenuhi hak-hak tersebut. Salah satu yang menarik dan menjadi permasalahan yang tak kunjung henti adalah hak politik bagi kaum disabilitas.

Data pemilih pada tahun 2018 menunjukkan bahwa sekitar 9 (Sembilan) juta pemilih yang merupakan penyandang disabilitas yang memiliki hak dan kesempatan yang sama untuk dinilai dengan perhitungan suara yang sama dengan orang normal pada umumnya (Kolamban, Liando, \& Sampe, 2019). Keterbatasan kemampuan harusnya bukanlah menjadi alasan untuk memangkas hak-hak seseorang terutama pada hak politiknya sebagai warga Negara, keterbatasan itu juga bukanlah menjadi alasan untuk diperlakukan diskriminatif karena pada faktanya banyak dari penyandang disabilitas tersebut yang bisa beraktifitas layaknya orang normal bahkan beberapa diantaranya bisa berkreasi melebihi kemampuan orang normal dengan caranya sendiri.

Sejauh yang penulis ketahui bahwa dari sekian banyak pelaksanaan pemilu fokus dari penyelenggara maupun pada perumus peraturan kepemiluan sebagian besar hanya pada fasilitas pemungutan suara bagi tunanetra dengan menyediakan alat bantu berupa brailer untuk memudahkan proses pencoblosan bagi penyandang tuna netra tersebut. Sebagaimana kita ketahui bahwa penyandang disabilitas tidak hanya terbatas pada tuna netra saja. Hasil yang telah disurvei sebelumnya oleh Nasional Jaringan Pendidikan Pemilih untuk Rakyat (JPPR), terdapat dua daerah yaitu Tangerang dan Pangkal Pinang tidak punya sama sekali Braille template, dengan alasan tidak ada mandat untuk menyediakannya (Afifuddin, Putra, \& Akbar, 2013). Hal yang kurang lebih sama juga terjadi di Makassar pada pemilihan walikota, seorang aktifis disabilitas memprotes 
desain braille template yang cukup membingungkan para pemilih "disabilitas netra" ketika hendak mencoblos (Salim, 2015). Aspek ini jugalah yang penulis coba untuk jabarkan bahwa fasilitas yang disediakan tersebut mempunyai keterbatasan yang hanya dapat digunakan oleh segelintir orang saja pada lingkungan tertentu pula.

Stigma yang berkembang dimasyarakat dan dapat dirasakan langsung kepada penyandang disabilitas adalah mobilisasi suara penyandang disabilitas hanyalah sebagai penambah jumlah hitungan suara tanpa adanya esensi perwakilan aspirasi untuk menyuarakan kepentingan mereka. Keikutsertaan penyandang disabilitas hanyalah secara sporadik pada momen pemilu saja tanpa mengenal calon yang nantinya akan mewakili suara mereka di kursi legislatif maupun eksekutif. Masyarakat diberikan ruang untuk berperan aktif dan menjadi bagian dari proses demokrasi. Menurut (Riwanto, 2018) bahwa semakin besar partisipasi akan mempunyai konsekuensi kian tinggi pula kualitas demokrasi (Afifuddin et al., 2013). Meski secara substansial keikutsertaan para pemilih penyandang disabilitas masih cenderung prosedural dan momentum saja.

Dari jabaran diatas penulis ingin menggambarkan bagaimana perspektif penyandang disabilitas dalam pendekatan psikologi politik terhadap keterbatasan dirinya jika diselaraskan dengan sistem pemilihan umum yang diterapkan dalam pemilu serentak tahun 2019.

Penelitian terdahulu menjadi landasan pemikiran penulis dalam melakukan penelitian serta memberikan gambaran tentang apa yang ingin diteliti oleh penulis. Penelitian terdahulu ini dijadikan sebagai referensi dan pembanding pada proses penelitian. Penelitian terdahulu yang dapat dijadikan landasan yaitu pertama, Penelitian (Merly, 2015) yang berjudul Aksesibilitas Pemilu 2014 dan Implikasinya Terhadap Ketahanan Politik (Studi Tentang Persepsi Mahasiswa Penyandang Disabilitas di Pusat Layanan Disabilitas UIN Sunan Kalijaga Yogyakarta).

Penelitian tersebut meneliti tentang aksesibilitas masih menjadi permasalahan dalam pemilihan umum 2014. Ketimpangan terhadap aksesibilitas pemilu bagi para penyandang disabilitas tentunya akan menimbulkan sebuah persepsi tersendiri dari mereka terhadap pelaksanaan pemilu. Mahasiswa penyandang disabilitas menilai buruk implementasi perundang-undangan yang telah banyak mengatur aksesibilitas, namun pijakan regulasi tidak mampu dilaksanakan dengan baik oleh penyelenggara pemilu untuk mendesain pemilu yang aksesibel bagi penyandang disabilitas.

Penelitian kedua yang menjadi landasan penelitian ini adalah Oktaviawan Yandarisman (Yandarisman \& Fitriyah, 2014). Penelitian yang telah dilakukan pada tahun 2013 itu menghasilkan kesimpulan bahwa PPUA PENCA telah melakukan sosialisasi bagi masyarakat disabilitas. Proses sosialisasi yang paling signifikan adalah mengadakan sosialisasi dalam bentuk seminar dengan mengundang pembicara dari KPU Provinsi, Bawaslu Pusat dan dari PPUA Penca. Materi yang disampaikan antara lain yaitu pengenalan visi misi calon Gubernur dan Wakil Gubernur.

Tata cara pencoblosan bagi masyarakat disabilitas, dan simulasi Pemilihan Umum bagi masyarakat disabilitas. Dengan adanya proses sosialisasi tersebut manfaat dan dampak yang dirasakan masyarakat disabilitas sangat besar dan dapat mengubah 
persepsi masyarakat disabilitas tentang politik dan pemilu. Proses sosialisasi yang dilakukan PPUA Penca kebijakan aksesibilitas penyandang cacat sudah ada, namun dirasa masih kurang memadai untuk mengakomodir seluruh kepentingan penyandang disabilitas dalam pelaksanaan pemilihan gubernur dan wakil gubernur.

Dari kedua hasil penelitian diatas sama-sama membahas mengenai pemilih disabilitas. Hanya tidak secara khusus membahas bagaimana perasaan atau kedirian dari seorang pemilih disabilitas yang menyalurkan atau tidak menyalurkan hak pilihnya dalam hal ini kendala dari faktor psikologis yang mereka hadapi. Selain itu, dalam penelitian tersebut diatas tidak menjabarkan kendala dalam tahapan pemilu yang secara langsung dihadapi oleh para pemilih disabilitas.

Pada penelitian ini kondisi yang dirasakan oleh para pemilih disabilitas dalam hal kedirian yang menjadi aspek internal dan aspek eksternal dalam proses yang berjalan langsung kaitannya dalam hal pemilu yakni tahapan-tahapan yang mereka hadapi secara langsung. Serta diharapkan dapat memberikan gambaran yang bisa menjadi pelengkap dari kedua penelitian diatas.

\section{Metode Penelitian}

Penelitian ini menggunakan pendekatan kualitatif dengan metode deskriptif. Menurut (Saifuddin, 1998) penelitian deskriptif melakukan analisis hanya sampai pada taraf deskripsi, yaitu menganalisis dan menyajikan fakta secara sistematik sehingga dapat lebih mudah dipahami dan disimpulkan (Azwar, 1998). Jenis penelitian ini akan menggambarkan secara faktual tentang hak pilih disabilitas dan bagaimana konsep kedirian dari seorang penyandang disabilitas dalam menggunakan atau tidak menggunakan hak pilihnya pada pemilu tahun 2019.

Beragam data diperoleh dari sumber sekunder seperti buku, artikel, jurnal, pemberitaan media, khususnya media online dan berbagai website yang menyediakan informasi terkait. Data kemudian diperoleh kemudian di analisis dengan menggunakan teknik reduksi data, penyajian data, dan penarikan kesimpulan yang menekankan pada ide dasar dari berbagai sumber yang di telah.

\section{Hasil dan Pembahasan}

Pemilihan Umum adalah instrument utama untuk mengukur kualitas pelaksanaan demokrasi di suatu Negara (Gaffar, 1999). Masyarakat diberikan ruang untuk berperan aktif dan menjadi bagian dari proses demokrasi. Menurut Undang-Undang Nomor 19 Tahun 2011 Tentang Pengesahan Hak-Hak Penyandang Disabilitas, penyandang disabilitas yaitu orang yang memiliki keterbatasan fisik, mental, intelektual atau sensorik dalam jangka waktu lama yang dalam berinteraksi dengan lingkungan dan sikap masyarakatnya dapat menemui hambatan yang menyulitkan untuk berpartisipasi penuh dan efektif berdasarkan kesamaan hak.

Menurut (Schneider Alexander, 1964) disabilitas adalah sebuah capaian dari interaksi antara seseorang dengan kondisi kesehatan tertentu dengan konteks atau lingkungan dimana seseorang itu berada. Upaya dalam memahami disabilitas, maka 
disabilitas tidak sekedar merujuk kepada individu seseorang. Disability should be understood by looking at levels of physical and personal functioning and how this interacts with environmental factors (Schneider Alexander, 1964).

Kelompok penyandang disabilitas termasuk kelompok minoritas jika dilihat dari segi jumlah mereka yang sedikit. Meski demikian, Undang-Undang No. 8 tahun 2016 tentang Penyandang Disabilitas telah menjelaskan bahwa Negara Kesatuan Republik Indonesia menjamin kelangsungan hidup setiap warga Negara. Pemilu 2019 masih belum bisa mengakomodasi kepentingan seluruh rakyat Indonesia yang plural, terkhusus bagi penyandang disabilitas.

Kondisi psikologi dari para penyandang disabilitas yang merasa bukan bagian dari pesta demokrasi dikarenakan adanya faktor eksternal yang kaitannya dengan lingkungan dimana mereka hidup dan faktor internal yang berkenaan dengan sikap, afeksi dan rasa kepercayaan diri. Umumnya, ketika individu mengalami rasa takut mereka ingin menghindar. Dan ketika individu mengalami kecemasan (anxiety), mereka terkadang tidak tahu sepenuhnya apa yang akan mereka lakukan sebagai respon, dan mereka cenderung untuk khawatir tentang apa yang harus dilakukan dan bagaimana melakukannya. Rasa takut juga muncul akibat persepsi yang muncul karena perbedaaan (Cottam, Dietz-Uhler, Mastors, \& Preston, 2012).

Di dalam psikologi politik salah satu pendekatan yang digunakan adalah teori psikoanalisis. Teori ini melihat suatu peran ketidaksadaran (unconsciousness) dalam manusia, serta motif-motif dan dorongan-dorongan (drive) yang mendasari perilaku seseorang. Perilaku merupakan hasil dari dorongan dengan usaha yang tidak disadari oleh individu untuk menahan dan menyalurkan peran oleh hasrat dalam mengambil keputusan.

Teori yang ditemukan dan dikembangkan oleh (Freud \& Strachey, 2001) berpendapat mengenai struktur kepribadian pada tiga elemen, yaitu Id, Ego, dan Superego yang bekerja sama untuk menciptakan perilaku manusia yang kompleks (Cottam et al., 2012).

1. Id (mencakup insting dan respon terhadap fungsi tubuh)

Id adalah satu-satunya komponen kepribadian yang hadir sejak lahir. Aspek kepribadian sepenuhnya sadar dan termasuk dari perilaku naluriah dan primitive. Freud mengatakan, id adalah sumber segala energy psikis hingga komponen utama kepribadian. Id merupakan sejumlah tren insting yang tidak terkoordinasi.

2. Ego (bagian yang sadar dengan realitas-realitas social)

Ego merupakan struktur kepribadian yang berada di tengah-tengah antara $I d$ dan Superego. Ego merupakan bagian yang terorganisasi dan realistis yang pada akhirnya akan memungkinkan perilaku, tetapi hanya di waktu yang tepat.

3. Superego (kata hati atau kekuatan moral)

(Hall \& Lindzey, 1978) menyebutnya sebagai tangan moral yang merupakan kesadaran kepribadian. Superego memberikan pedoman untuk membuat penilaian dan memainkan peran kritis dan moral. 
Diantara ketiga struktur kepribadian tersebut, Ego merupakan struktur yang paling penting. Kemampuan Ego dalam mendamaikan Id dan Superego akan mempengaruhi akal budi seseorang. Ketika Ego terancam, yaitua ketika Ego tidak mampu mendamaikan dorongan Id dengan Superego maka individu akan merasa cemas, baik cemas yang realistis maupun cemas yang bersifat neurotic (Neurotic Anxiety) yaitu ketakutan akan hukuman karena melakukan suatu tindakan atas dorongan $I d$. Kecemasan yang lainnya adalah kecemasan moral (Moral Anxiety) yang muncul ketikan terjadi konflik antara $I d$ dan Superego.

Dalam menguraikan dan membahas psikologi baik dari sisi kepribadian, proses berfikir, emosi dan motivasi orang-orang yang terlibat dalam aktivitas politik dapat memberikan suatu dasar yang unik dalam memahami politik. Psikologi politik menguraikan dan menjelajahi batas antara gagasan intelektual dari ilmu politik dan psikologi yang menjelaskan mekanisme bagaimana institusi politik mempengaruhi perilaku manusia dan sebaliknya bagaimana manusia mempengaruhi institusi politik (Jost \& Sidanius, 2004).

Jika politik dan psikologi bertemu dan bergandengan tangan maka itulah yang disebut dengan psikologi politik. Psikologi politik adalah suatu bidang ilmu yang menguji hubungan antara psikologi dan politik. Psikologi politik merupakan kajian antar disiplin ilmu yang menggunakan pendekatan multi-metode dalam mengkaji fenomena politik pada tingkat individu. Dalam konteks ini, psikologi politik memiliki peran penting dan signifikan dalam menjelaskan proses-proses psikologis di balik sikap, perilaku, pengambilan keputusan, dan interaksi antara individu dan kelompok (Erişen, 2012).

Pada dasarnya psikologi politik mewakili penggabungan dua disiplin, psikologi dan ilmu politik. Psikologi politik menyangkut penjelasan tentang apa yang dilakukan orang-orang, dengan mengadaptasi konsep-konsep psikologi, sehingga konsep-konsep ini bermanfaat dan relevan dengan politik, kemudian mengaplikasikannya pada analisis tentang suatu masalah atau isu politik.

Konsep psikologi politik memberikan penjelasan tentang sisi kepribadian manusia yang memiliki pikiran, emosi dan perilaku dalam aktivitas politik. Penyandang disabilitas merupakan bagian dari warga negara yang termasuk dalam kajian psikologi politik. Dalam konteks penelitian ini, konsep psikologi politik ini menjadi tahap awal untuk membahas dan menjawab permasalahan sikap, afeksi atau suasana hati pemilih disabilitas yang tentu saja berkaitan dengan sisi kepribadian makhluk politik.

Terdapat beberapa tahapan Pemilu yang secara langsung oleh para pemilih penyandang disabilitas terlibat di dalamnya, diantaranya:

1. Sosialisasi

Tahapan sosialisasi adalah peletakan tonggak dasar dari pelaksanaan pemilu dan merupakan upaya untuk menarik minat serta pemberian pemahaman kepada warga Negara sebagai wajib pilih untuk dapat menyalurkan aspirasinya. Beban pelaksanaan tahapan ini sepenuhnya berada pada penyelenggara pemilu dan dibantu pihak-pihak terkait. Penyampaian informasi dan pengetahuan tentang kepemiluan 
akan meningkatkan kesadaran masyarakat akan pentingnya pemilu dan pentingnya partisipasi mereka untuk menentukan masa depan bangsa.

Korelasi antara sosialisasi, penyediaan fasilitas, dan perhatian khusus kepada penyandang disabilitas pada kenyataannya masih terpaut jauh mengingat masih minimnya pengejawantahan amanat undang-undang kepada penyandang disabilitas dalam pelaksanaan pemilu. Minimnya sosialisasi ini memaksa penyandang disabilitas untuk tidak mengindahkan asas kerahasiaan dalam memberikan suaranya ataupun memilih untuk tidak menyalurkan hak suaranya sama sekali.

2. Pemutakhiran Data Pemilih

KPU telah melakukan klasifikasi jenis penyandang disabilitas berdasarkan petunjuk teknis dari peraturan komisi pemilihan umum dalam Daftar Pemilih Tetap (DPT) atau Pemutakiran Data Pemilih. Dalam format DPT pemilih disabilitas mencantumkan jenis penyandang disabilitas dengan tujuan untuk memberikan pelayanan kepada penyandang disabilitas dan sebagainya. Terdapat beberapa jumlah penyandang disabilitas di Indonesia. Namun dari penamaan pemilih disabilitas dalam DPT hanya sebatas tuna daksa, tuna netra, tuna rungu atau wicara, tuna grahita dan disabilitas lainnya. Padahal di dalam UU No. 8 Tahun 2011 Pasal 4 ayat 1 terkait ragam penyandang disabilitas juga termasuk didalamnya penyandang disabilitas mental akan tetapi di dalam formulasi daftar pemilih tetap khususnya disabilitas tidak terdapat penyandang disabilitas mental. Dan dari hasil penelitian dilapangan menunjukkan bahwa masih banyak badan ad-hock KPU yang terkadang bingung bahkan ada yang tidak paham dengan istilah penamaan pemilih disabilitas. Dalam penelitian ini juga ditemukan adanya pemilih disabilitas yang tidak terdata oleh badan ad-hock KPU meski pemilih tersebut memiliki KTP.

3. Pemungutan Suara

KPU berkoordinasi secara berjenjang dengan PPK, PPS, dan KPPS melalui petunjuk teknis dari pembuatan TPS yang aksesibel. TPS merupakan hal yang krusial sebab jika TPS tidak aksesibel, dapat dipastikan pemilih disabilitas tentu mendapat kesulitan dalam mengakses informasi maupun dalam penyaluran hak pilihnya.

Di beberapa TPS masih banyak yang belum memperhatikan akses bagi pemilih penyandang disabilitas yang sesuai dengan aturan yang berlaku. Hal ini karena kurangnya pemahaman atau kesadaran penyelenggara tentang jenis-jenis kebutuhan dari penyandang disabilitas yang berbeda sesuai jenis disabilitas yang disandangnya. Sehingga tidak sedikit para pemilih disabilitas seperti disabilitas fisik yang merasa tidak percaya diri ketika berada di dalam TPS. Demikian halnya pada disabilitas rungu ketika berada di dalam bilik suara, dimana asas "luber" sudah tidak menjadi pilihannya ketika yang mengantarkan ke dalam bilik juga ikut melihat apa yang mereka coblos.

4. Penghitungan Suara dan Hasil Pemilu

Dalam prakteknya pemahaman umum dari masyarakat maupun dari penyelenggara pemilu sendiri adalah bahwa alur kepentingan dari penyandang disabilitas hanya akan berhenti pada tahap pemungutan suara saja, sehingga kesan 
yang timbul adalah hanyalah suaranya dalam pemilu sebagai pelengkap jumlah hitungan dalam lembaran formulir C. Kondisi ini menempatkan penyandang disabilitas dalam posisi yang semakin termarjinalkan dengan akses informasi hasil pemilu yang berakhir di papan hasil pemungutan suara tanpa ada lagi upaya khusus dari penyelenggara pemilu kepada penyandang disabilitas seperti pada tahap sosialisasi dan pendataan wajib pilih.

Kesempatan yang sama pada tahap ini menjadi kabur sehingga kesempatan untuk mengakses hasil pemilu menjadi sulit terlebih dalam penyampaian aspirasi lanjutan kepada wakil yang telah mereka pilih dalam bilik TPS untuk dapat mewujudkan keterbatasannya dalam kehidupan bernegara.

\section{Kesimpulan}

Kesimpulan dari penelitian ini adalah selain dipengaruhi oleh kondisi psikologis internal, bahwa persepsi dan psikologi politk penyandang disabilitas juga banyak dipengaruhi oleh faktor pelayanan dari penyelenggara pemilu, system kepemiluan/ regulasi pemilu, sosialisasi dan informasi, serta penyediaan fasilitas yang memudahkan penyandang disabilitas untuk dapat mengakses pelaksanaan pemungutan suara.

Untuk mencapai kondisi tersebut diatas diperlukan pemahaman dan upaya yang lebih dari penuyusun undang-undang untuk dapat lebih menjangkau hak-hak penyandang disabilitas dan juga peningkatan kualitas penyelenggara pemilu untuk dapat memberikan pemahaman dan pelayanan secara komprehensif, karena pelaksanaan pemilu yang paripurna adalah dengan terserapnya suara seluruh wajib pilih dengan kesadaran penuh dan keyakinan dari wajib pilih itu sendiri untuk menyalurkan hak suaranya. 


\section{BIBLIOGRAFI}

Afifuddin, Mochammad, Putra, Rudiansyah, \& Akbar, Andika. (2013). Aplikasi Artificial Neural Network (ANN) Untuk Memprediksi Perilaku Lentur Profil Kanal (C) Ferosemen. Jurnal Teknik Sipil, 2 (2), 117-126. Google Scholar

Azwar, Saifuddin. (1998). Metode Penelitian Kualitatif. Yogyakarta: Pustaka Pelajar. Google Scholar

Cottam, Martha L., Dietz-Uhler, B., Mastors, E., \& Preston, T. (2012). Pengantar psikologi politik. Edisi Kedua. Jakarta: Raja Wali Pers. Google Scholar

Erişen, Elif. (2012). An introduction to political psychology for international relations scholars. Perceptions: Journal of International Affairs, 17 (3), 9-28. Google Scholar

Freud, Sigmund, \& Strachey, James. (2001). The Complete Psychological Works of Sigmund Freud Vol. 11: Five Lectures on Psychoanalysis Leonardo Da Vinci \& Other Works (Vol. 11). Random House. Google Scholar

Gaffar, Afan. (1999). Politik Indonesia: transisi menuju demokrasi. Pustaka Pelajar. Google Scholar

Hall, C. S., \& Lindzey, G. (1978). Theories of Personalities (3th edt.). New York: John Willey \& Sons. Google Scholar

Jost, John T., \& Sidanius, Jim. (2004). Political psychology: Key readings. Psychology Press. Google Scholar

Kolamban, Gabriela Aprilia, Liando, Daud, \& Sampe, Stefanus. (2019). Kinerja Komisi Pemilihan Umum Daerah Dalam Penyusunan Daftar Pemilih Tetap Pada Pemilihan Kepala Daerah Kabupaten Minahasa Tahun 2018. Jurnal Eksekutif, 3 (3). Google Scholar

Merly, Mario. (2015). Aksesibilitas Pemilu 2014 Dan Implikasinya Terhadap Ketahanan Politik (Studi Tentang Persepsi Mahasiswa Penyandang Disabilitas Di Pusat Layanan Difabel UIN Sunan Kalijaga Yogyakarta). Jurnal Ketahanan Nasional, 21(2), 61-77. Google Scholar

Riwanto, Agus. (2018). Alasan Mengapa Golput Pemilu 2014 Turun. Majalan Kontan, 4. Google Scholar

Saifuddin, Azwar. (1998). Metode Penelitian, cet. Ke-1. Yogyakarta: Pustaka Pelajar. Google Scholar

Salim, Ishak. (2015). Perspektif Disabilitas dalam Pemilu 2014 dan Kontribusi Gerakan Difabel Indonesia bagi Terbangunnya Pemilu Inklusif di Indonesia. Jurnal Administrasi Dan Kebijakan Kesehatan Indonesia, 1 (2), 127-156. Google Scholar 
St. Syamsuri. R, Gustiana A. Kambo, Muhamad Rasman

Schneider Alexander, A. (1964). Personal Adjustment and Mental Health. New York: Winston. Google Scholar

Yandarisman, Oktaviawan, \& Fitriyah, Fitriyah. (2014). Peran Panitia Pemilihan Umum Akses Penyandang Cacat (PPUA Penca) Dalam Sosialisasi Politik Bagi Masyarakat Difabel Dalam Pemilihan Umum Gubernur Dki Jakarta 2013. Diponegoro University. Google Scholar

\section{Copyright holder:}

St. Syamsuri. R, Gustiana A. Kambo, Muhamad Rasman (2021)

First publication right:

Jurnal Syntax Admiration

\section{This article is licensed under:}

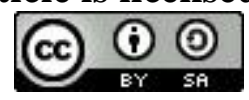

